\title{
Integrating water management and principles of policy: towards an EU framework?
}

\author{
Aad Correljé $^{\text {a }}$, Delphine François ${ }^{\mathrm{a}, \mathrm{b}, *}$, Tom Verbeke ${ }^{\mathrm{b}, \mathrm{c}}$

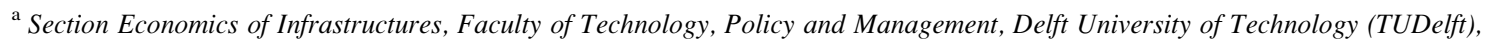 \\ Jaffalaan 5, 2628 BX Delft, The Netherlands \\ ${ }^{\mathrm{b}}$ Centre for Environmental Economics and Environmental Management (CEEM), Faculty of Economics and Business Administration, \\ Ghent University (UGent), Hoveniersberg 24, 9000 Gent, Belgium \\ ${ }^{\mathrm{c}}$ Centre for Corporate Sustainability (CEDON), European University College Brussels (EHSAL), Stormstraat 2, 1000 Brussels, Belgium
}

Received 1 January 2005; accepted 31 July 2006

\begin{abstract}
The EU Water Framework Directive requires Member States to organise the management of their water systems in an integrated manner, based on the natural boundaries of the water systems; the river basins. A river basin approach implies the integration of policymaking and management throughout a set of different functional uses and spatial scales. Another innovation of the Directive is the introduction of recovery of costs for water services, taking account of the polluter-pays principle. By 2010, water-pricing polices will have to provide adequate incentives for users to use water resources efficiently, and thereby contribute to the environmental objectives of the Directive. Other principles, such as the precautionary principle, are becoming increasingly important in the management of water resources as well. The translation of those principles into policy in the several Member States may however diverge. We present an overview of policy principles that play a role as basic assumptions in water management. Environmental policy principles have gradually been introduced in European legislation. From being part of a declaration of the Council, they have evolved to a basis for action in the environmental field and currently they also find wide application in the context of water management. While focusing on the EU Water Framework Directive, we investigate whether and how these principles can be reconciled with a framework for integrated water management.
\end{abstract}

(C) 2006 Elsevier Ltd. All rights reserved.

Keywords: EU Water Framework Directive; Polluter-pays principle; Precautionary principle; EU environmental policy

\section{Introduction}

Environmental principles of policy have become increasingly important in water management, both internationally as well as on the national level. After giving an overview of the main environmental policy principles, we analyse their gradual introduction into European legislation. This evolution is also reflected more specifically in water management, which

\footnotetext{
* Corresponding author. Centre for Environmental Economics and Environmental Management (CEEM), Faculty of Economics and Business Administration, Ghent University (UGent), Hoveniersberg 24, B-9000 Gent, Belgium. Tel.: +329264 3478; fax: +3292643599.

E-mail address: Delphine.Francois@UGent.be (D. François).
}

on the European level culminated in the adoption of the Water Framework Directive. Different institutional contexts may however imply a different interpretation and practical implementation of the principles concerned, and therefore lead to different results. We emphasize the importance of paying proper attention to the specific institutional contexts when comparing and evaluating the ways in which environmental principles of policy are approached.

\section{Environmental policy principles: an overview}

Environmental policy, be it at international, national or regional level, is increasingly guided by environmental policy principles. After having defined the most widespread 
environmental principles of policy, this section gives an overview of how they have gradually been introduced into European legislation. The definitions of the principles in this paragraph are provided by the European Environment Agency [1].

\subsection{Defining the principles}

The precautionary principle was adopted by the UN Conference on the Environment and Development [2]. According to the precautionary approach, where there are threats of serious or irreversible damage to the environment, lack of full scientific certainty should not be used as a reason for postponing cost-effective measures to prevent environmental degradation. According to the Rio Declaration on Environment and Development, the precautionary approach shall be widely applied by States according to their capabilities. The opposite view is reflected in the wait-and-see principle, which outlines a reactive method of dealing with the environment that places the burden of proof on those who would conserve. A less far-reaching principle than the precautionary principle is the prevention principle, which allows action to be taken to protect the environment at an early stage, the underlying idea being that it is better to prevent than to repair. Also related to prevention is the source principle, which specifies that environmental damage should preferably be prevented at the source, rather than by using the 'end-of-pipe technology'. It also implies a preference for emission standards rather than environmental quality standards, especially to deal with water and air pollution.

The polluter-pays and the user-pays principle are both related to who should bear the costs of environmental degradation. According to the polluter-pays principle (PPP), those who cause pollution should meet the costs to which it gives rise, whereas the user-pays principle calls upon the user of a natural resource to bear the cost of running down natural capital. The polluter-pays principle was adopted by the Organisation for Economic Cooperation and Development (OECD) in 1972 as the principle to be used for allocating costs of pollution prevention and control measures to encourage rational use of scarce environmental resources and to avoid distortions in international trade and investment. It means that the polluter should bear the expenses of carrying out the above-mentioned measures decided by public authorities to ensure that the environment is in an acceptable state [3]. The principle was introduced in the Single European Act [4]. It had previously been referred to in national legislation and EC directives [5]. As the precautionary principle, it is included in the Rio Declaration adopted at the 1992 United Nations Conference on Environment and Development, which states that "National authorities should endeavour to promote the internalization of environmental costs and the use of economic instruments, taking into account the approach that the polluter should, in principle, bear the cost of pollution, with due regard to the public interest and without distorting international trade and investment".

The economic principle that the polluter should pay is designed to achieve a better allocation of resources by ensuring that prices of goods depending on the quality and/or quantity of environmental resources reflect more closely their relative scarcity [3]. Although when establishing the PPP the OECD referred to the fact that costs of pollution prevention and control measures should be reflected in the costs of goods and services, there were no explicit requirements that those costs should be reflected in the prices charged to consumers.

Other principles are more specifically related to certain environmental fields, such as e.g. waste management, where the EC Framework Directive on waste can be mentioned, which established both the principle of self-sufficiency (requiring that most waste should be treated or disposed of within the region in which it is produced) and the principle of proximity (implying that waste should generally be managed as near as possible to its place of production, mainly because transporting waste has a significant environmental impact).

\subsection{Environmental policy principles in European legislation}

When the representatives of the Belgian, Dutch, Italian, French, German and Luxemburg governments were negotiating the treaties of Rome in the mid to late 1950s, the environment was not part of their agenda. The objective of their enterprise which was called the European Economic Community (EEC) was "to promote throughout the Community a harmonious development of economic activities, a continuous and balanced expansion, an increase in stability, an accelerated standard of living and closer relations between the States belonging to it" (art. 2 EC-1958). ${ }^{1}$ In order to reach this objective, the Treaty of Rome mentions the establishment of a common market and the progressive approximation of economic policies of the Member States as the major means (art. 2 EC-1958). Article 3 of EC-1958 clarifies which activities should be included in the work of the EU. This article includes references to the elimination of customs duties and quantitative restrictions on intra-EU trade, the establishment of a common external tariff, the abolition of obstacles on the freedom of movement of persons, services and capital, the adoption of common policies in agriculture and transport, the institution of a system which ensures that competition is not distorted, the establishment of a European Social Fund and European Investment Bank, the association of overseas countries and territories and the application of procedures to coordinate Member State's economic policies. The EU was also able to introduce measures to approximate the law of

\footnotetext{
${ }^{1}$ The EEC was founded by the Treaty of Rome, which was signed in 1958. The Treaty of Rome has been changed by the Single European Act (SEA), which was signed in 1986, The Treaty on European Union (Treaty of Maastricht) signed in 1992, The Treaty of Amsterdam signed in 1997 and the Treaty of Nice signed in 2001. All these treaties amended the original treaties of Rome. Whereas the SEA and the Treaty of Maastricht kept the original treaty article numbers, the Treaty of Amsterdam changed them. In the text, we will refer to the original treaties as EC-1958, to the treaty as amended by the SEA as EC-1986, by the Treaty of Amsterdam as EC-1997 and as amended by the Treaty of Nice as EC-2001. The Treaty Establishing a Constitution for Europe (Constitution) has not yet been ratified by all EU Member States. The Treaty of Maastricht introduced the "European Union (EU)". We will use the "EU" even if we refer to acts prior to 1992.
} 
the Member States to the extent required for the proper functioning of the common market (art. 3h EEC-1958). A common environmental policy or the approximation of the laws of the Member States in environmental matters was not on the list. As such, that lack of a reference to the environment or environmental quality is not a big surprise. Environmental pollution was, at the time the treaty was being negotiated, not a matter of concern.

The latter, however, changed quite soon. By 1968 the UN's General Assembly was concerned enough that it adopted resolution 2398 XXIII calling upon the Secretary-General of the $\mathrm{UN}$ to collect data on the state of the environment in the world [6]. A year later, the report "Man and His Environment" contains the warning that "There is no doubt that ... future life on earth will be threatened" if man continues to pollute the environment [6]. After a series of regional conferences on the state of the environment, the UN's Conference on the Human Environment which met in Stockholm from 5 to 16 June 1972 adopted a declaration which clearly states that the "protection and improvement of the human environment is a major issue which affects the well-being of peoples and economic development throughout the world" (Declaration of the UN Conference on the Human Environment). Hence, 14 years after the Treaty of Rome came into effect, the environment was a major concern.

At a summit in October 1972 in Paris, the Heads of State or of Government of the EU emphasized the importance of an environmental policy at the EU level and they invited the other EU institutions to establish a program of action. On 22 November 1973, the first Environmental Action Program (EAP1) was adopted by a declaration of the Council [7]. Although it is not legally enforceable, this action program is important as it sets out a number of principles which have served and continue to do so as the basis of the EU's environmental policy. Furthermore, the EAP-1 established a clear link between the objectives mentioned in article 2 EC-1958 and the quality of the environment. The EAP-1 states that the objectives "cannot now be imagined in the absence of an effective campaign to combat pollution and nuisances or of an improvement in the quality of life and the protection of the environment". Summarized, the principles that were listed in the EAP-1 are:

1. Prevention is better than cure

2. Effects on the environment should be taken into account at the earliest possible stages in all technical planning and decision-making processes

3. Any exploration of natural resources or of a nature which causes significant damage to the ecological balance must be avoided

4. The standard of scientific knowledge should be improved

5. The polluter pays principle: the cost of preventing and eliminating nuisances must, in principle, be born by the polluter

6. Activities in one state should not cause degradation of the environment in another state

7. Environmental policies should take into account the interest of developing countries
8. Member States should cooperate in international environmental policy decision-making

9. Every citizen of the EU should be educated on environmental issues as this is a necessity to raise awareness and to assume the responsibility in full towards the generations to come

10. For various categories of pollution, it is necessary to establish the appropriate level of action (local, regional, national, EU, international)

11. National environmental policies should be coordinated within the EU

These principles were reaffirmed in the Second Environmental Action Program (EAP-2), which was adopted by the Council on 17 May 1977 [8]. The third Environmental Action Program (EAP-3) focused more particularly on the second principle and stressed the need to integrate environmental concerns into other policy areas [9]. More specifically, it argued that "Environmental impact assessment is the prime instrument for ensuring that environmental data is taken into account in the decision-making process". The EAP-3 argued that impact assessment should be gradually introduced into the planning and preparation stages of human activities. Secondly, the EAP-3 introduced the regional dimension in EU environmental policy making when it refers to the fact that the environmental policy should pay more attention to the gaps between the levels of development of the regions in Europe. The fourth Environmental Action Program (EAP-4) builds on the impact assessments and the regional dimension of the EU's environmental policies [10].

As the EU's environmental policy activity increased, so too did the need to have a proper framework within the treaty. As long as there was no such basis, the EU was required to base its decisions on articles of the treaty that were not designed to be used as basis for environmental policy making. The legal basis was formed by article 100 EC-1958 and 235 EC-1958. The former authorized directives affecting the functioning of the common market while the latter allowed the EU to take action in those areas not provided for in the treaty. However, both required a unanimous Council decision. The negotiations on the Single European Act (SEA) were used to give the EU's environmental policy a proper legal framework. The SEA introduced a new title IV: Environment to Part Three of the EEC Treaty: Policy of the Community. The new title on the environment introduced articles 130r to $130 \mathrm{t}$ to the treaty, which defined the objectives and principles of the EU's environmental policy. The objectives of the EU's environmental policies are "i) to preserve, protect and improve the quality of the environment; ii) to contribute towards protecting human health and iii) to ensure a prudent and rational utilization of natural resources" (art. 130r para. 1 EC-1986). In order to reach this objective, "action by the Community shall be based on the principles that preventive action should be taken, that environmental damage should as a priority be rectified at the source and that the polluter should pay" (art. 130r para. 2 EC-1986). Furthermore, the SEA introduced the concept that "Environmental protection requirements shall be a component 
of the Community's other policies" (art. 130r para. 2 EC-1986). Other principles mentioned in the EAP-1 and introduced in the environmental title were the fact that the Community will only take action if the objectives of such action can be better attained at the EU level compared to the level of the Member States, i.e. the subsidiarity principle (art. 130r para. 4 EC-1986) and that the EU and its Member States shall cooperate in international environmental decision-making (art. 130r para. 5 EC-1986).

The 'status' of 'the environment' had greatly improved in the EC-1986 compared to the EC-1958. First of all, it became a formal policy of the community to preserve, protect and improve the quality of the environment. Secondly, the policy principles which were until then only part of a declaration of the Council, became much more formal as they were (and still are) a proper basis for action in the environmental field. However, the quality of the environment was not a part of the ultimate objective of the EU nor was it the object of a policy listed in art. 3 EC-1986.

The latter was accomplished six years after the SEA with the Treaty of Maastricht. Following the Report of the World Commission on Environment and Development [11], the Maastricht Treaty changes the objectives of the EU. The EU's objective is "to promote throughout the Community a harmonious and balanced development of economic activities, sustainable and non-inflationary growth respecting the environment, a high degree of convergence of economic performance, a high level of employment and of social protection, the raising of the standard of living and quality of life, and economic and social cohesion and solidarity among Member States" (art. 2 EC-1992). Furthermore, "a policy in the sphere of the environment" is explicitly referred to in art. 3 para. $\mathrm{k}$ of the EC-1992. The inclusion of a reference to sustainable growth and the explicit mentioning of environmental policies as one of the spheres where the community has to act in order to reach its objective are clearly indicative of the fact that the EU was convinced that sustainability has become one of the leading guiding principles in the EU.

The Maastricht Treaty also amended articles 130r to 130t. First of all, the subsidiarity principle was removed from the environmental title as it became an overall principle of EU decision-making. Secondly, a fourth objective was added to article 130r. From 1992 onwards, the EU's environmental policy also includes "promoting measures at international level to deal with regional or worldwide environmental problems" (art. 130r para. 1 EC-1992) as one of its objectives. Thirdly and in terms of principles and means of environmental policy, most importantly, art. 130r para. 2 EC-1992 now requires that "Community policy on the environment shall aim at a high level of protection taking into account the diversity of situations in the various regions of the Community". Furthermore, "It shall be based on the precautionary principle and on the principles that preventive action should be taken, that environmental damage should as a priority be rectified at source and that the polluter should pay. Environmental protection requirements must be integrated into the definition and implementation of other Community policies." Clearly, art. 130r
EC-1992 introduces a high level of protection, the diversity of situations and the precautionary principle as key guidelines and policy principles.

The EAP-4 also focuses on the principle 9 mentioned in the EAP-1: information and education of citizens. The EAP-4 indicated that the EU Commission would start to publish 'state of the environment reports' in 3-year cycles and that it would, following a request by the European Parliament, come with proposals on the right to access environmental information. In 1990, directive 90/313/EEC on freedom of access to environmental information, which was repealed in 2003 by directive 2003/4/EC covering the same issue, ensures the freedom of access to information on the environment [12].

The Treaty of Amsterdam, which was signed in 1997 and went into force on 1 May 1999, renumbered the articles in the treaty. As far as the environmental title is concerned, this renumbering was the only change: art. 130r EC-1992 became art. 174 EC-1997; art. 130s EC-1992 became art. 175 EC-1997 and art. 130t EC-1992 became art. 176 EC-1997. Although little has changed with the Treaty of Amsterdam, there are three notable exceptions. First of all, the objective of the EU now includes a clear reference to sustainable development as it states that the EU's objectives include "a harmonious, balanced and sustainable development of economic activities". Also art. 2 EC-1997 goes a step further in terms of the environmental policy goals: among the EU's objectives, this article now refers to "a high level of protection and improvement of the quality of the environment". Secondly, the treaty introduces a new article 6 in the title containing the overall principles of the EU which states that "Environmental protection requirements must be integrated into the definition and implementation of the Community policies and activities referred to in Article 3, in particular with a view to promoting sustainable development" (art. 6 EC-1997). Hence, the treaty now explicitly refers to the fact that environmental considerations should be an integral part of all policies of the EU. A third change concerns decision-making: with a few exceptions, environmental regulations will be decided using the co-decision procedure, which implies an increase in the power of the European Parliament.

The Nice Treaty did not change the environmental policy principles. Although it was envisaged that it would change the unanimity requirement for issues such as eco-taxes, this goal was not accomplished. The text of the European Convention includes a section on the environment, the major principles of the EU's environmental policy are still those from the EU-1997 treaty.

\section{Water management and principles of policy}

The principles of policy discussed in Section 2 have been gradually introduced into European legislation and they currently find wide application in the context of water management. As an example, both the precautionary principle as well as the source principle are mentioned in the Drinking Water Directive (Council Directive 98/83/EC of 3 November 1998 on the quality of water intended for human consumption [13]). 
The most recent European Directive in the context of water management is the EU Water Framework Directive (Directive 2000/60/EC of the European Parliament and of the Council of 23 October 2000 establishing a framework for Community action in the field of water policy). The ultimate aim of this Directive is to achieve the elimination of priority hazardous substances and contribute to achieving concentrations in the marine environment near background values for naturally occurring substances (Directive 2000/60/EC). The EU Water Framework Directive (WFD) puts forward a system of water management based on coordination of administrative arrangements within river basin districts instead of according to administrative or political boundaries. The importance of carrying out integrated water resources management at the level of the catchment basin or sub-basin had already been stressed in Chapter 18 ("Protection of the quality and supply of freshwater resources: application of integrated approaches to the development, management and use of water resources") of Agenda 21. The main environmental objectives of the WFD are to prevent deterioration of the status of all bodies of surface and groundwater and to achieve good surface and groundwater status at the latest 15 years after the date of entry into force of the Directive. For artificial and heavily modified bodies of water, Member States should aim to achieve good ecological potential and good surface water chemical status. Less stringent environmental objectives, e.g. when the natural condition of specific bodies of water is such that achievement would be disproportionately expensive, are allowed under certain conditions. One of the elements that is taken into account in those conditions is the fact whether costs are disproportionate or not.

One of the important innovations of the WFD is the introduction of pricing of water services. The costs of water services will have to be recovered taking account of the polluter-pays principle. This principle of recovery of the costs of water services is set out in Article 9, which states that "Member States shall take account of the principle of recovery of the costs of water services, including environmental and resource costs, having regard to the economic analysis conducted according to Annex III, and in accordance in particular with the polluter pays principle" [14]. By 2010, water-pricing policies have to provide adequate incentives for users to use water resources efficiently and thereby contribute to the environmental objectives of the Directive. The cost recovery should be disaggregated at least to the levels of industry, households and agriculture. Complying with Article 9 of the European Water Framework Directive will necessitate a review of the impact of human activity on the status of surface waters and on groundwater and an economic analysis of water use for each river basin district. This requirement has been set out in Article 5. It should be noted that in complying with Article 9, Member States may take social, environmental, and economic effects of the cost recovery into account, as well as the geographic and climatic conditions of the region or regions affected.

In order to reach the different objectives that have been set out in the WFD, programmes of measures need to be established for each river basin district. Every programme needs to include the "basic measures", which are the minimum requirements to be complied with, and, where necessary "supplementary" measures. The WFD also involves the encouragement of public participation in its implementation, in particular with respect to the river basin management plans that need to be produced for each river basin district.

Although the polluter-pays principle is explicitly mentioned several times, e.g. with respect to the recovery of costs for water services, it is not the only policy principle of importance within the WFD. Already at the outset reference is made to Article 174 of the Treaty, which sets out that "the Community policy on the environment is ... and to be based on the precautionary principle and on the principles that preventive action should be taken, environmental damage should, as a priority, be rectified at source and that the polluter should pay". According to Preamble 44, "In identifying priority hazardous substances, account should be taken of the precautionary principle, relying in particular on the determination of any potentially adverse effects of the product and on a scientific assessment of the risk" (EU, 2000). The environmental objectives of the Directive (Article 4) reflect the importance of the principles. As the prevention of (further) pollution is one of the purposes of the Directive, the prevention principle is given a major role. Whether or not good water status (in the case of surface water and groundwater) and good ecological potential and good surface water chemical status (in the case of artificial and heavily modified bodies of water) is achieved depends on the realization of quality standards that are set out in Annex V of the Directive. For the concentrations of priority substances in surface water, sediments or biota, quality standards are also of importance in the strategies against pollution. The objective to progressively reduce pollution from priority substances and cease or phase out emissions, discharges and losses of priority hazardous substances (for surface waters) can nevertheless also be related to the source principle, which reflects a preference for emission standards rather than environmental quality standards. This also applies to the objective to prevent or limit the input of pollutants into groundwater. Similar references to the principles of policy can also be found in the description of basic measures that Member States need to include in their programmes of measures for each river basin district.

Other examples of the application of the principles of policy in the context of water management are numerous. The 1992 United Nations Economic Commission for Europe (UNECE) Convention on the protection and use of transboundary watercourses and international lakes, for example, explicitly mentions the precautionary and polluter-pays principle as guiding principles, and also requires water resources to be managed so that the needs of the present generation are met without compromising the ability of future generations to meet their own needs when managing water resources [15]. Reference is also made to the source principle and the importance of prevention. The UNECE Water Convention, which was adopted in Helsinki in 1992 shortly before the Rio Conference, provides a legal framework for regional cooperation on 
shared water resources (rivers, lakes and groundwaters). It entered into force in 1996 [16] and is referred to in the WFD as a Community obligation under international conventions on water protection and management. The importance of environmental principles of policy when implementing measures in the context of water pollution prevention and control is also highlighted in Chapter 18 of Agenda 21 [17].

Environmental policy principles have already been included in national legislation long before the Water Framework Directive was adopted. In The Netherlands, for example, the polluter-pays and user-pays principles are guiding principles in water management. Since the Surface Water Pollution Act (1970) came into operation a charge on pollution is imposed to finance water quality management, while in water quantity management there is a long tradition of relating levies to the interest of stakeholders [18].

\section{The institutional context: towards an integrated approach?}

Environmental policy principles such as the polluter-pays principle and the precautionary principle are widespread throughout European legislation; their actual implementation however depends on a series of factors. The fact that e.g. different pollution assimilative capacities of the environment, different social objectives and priorities attached to environmental protection and different degrees of industrialization and population density justify differing national environmental policies was already recognized by the OECD when the polluter-pays principle was put forward in 1972. Although Article 174 of the Treaty recognizes the importance of the several policy principles, "Community policy on the environment shall aim at a high level of protection taking into account the diversity of situations in the various regions of the Community" ... "In preparing its policy on the environment, the Community shall take account of available scientific and technical data; environmental conditions in the various regions of the Cотmunity; the potential benefits and costs of action or lack of action; and the economic and social development of the Community as a whole and the balanced development of its regions". The importance of regional and local conditions is also stressed within the WFD. Many factors influence the development of national water management systems. Geography and hydrology, for example, constrain local development since they shape patterns of quantitative and qualitative availability, determine the territorial size and the technical complexity of water infrastructure, require to a larger or smaller extent appropriate institutional developments in the model of water governance and so on [19].

As an example, the views on precisely what external environmental costs the polluter-pays principle should be concerned with vary. In most interpretations of the polluter-pays principle, the appropriate level of internalization of external environmental costs is left for public authorities to decide domestically [4]. According to OECD 1992 [5], the principle, as defined in 1972, has progressively been generalized and extended. From being a principle of partial internalization, it is increasingly become a principle of full internalization. It not only covers pollution prevention and control costs (aside from certain exceptions), but also the costs of administrative measures taken by the authorities as a result of pollutant emissions. The principle is progressively extended to the cost of damage caused by pollution. This tendency was formalized in 1991, when the OECD adopted a Recommendation on the use of economic instruments which states that sustainable and economically efficient management of environmental resources requires the internalization of pollution prevention, control and damage costs [5]. The Rio Declaration for example is in favour of the full internalization of environmental costs, including damage costs.

It is not always easy to deduct just charges and prices from hydrological cause-effect relations, as van Hijum [18] has demonstrated for attempts in The Netherlands to implement the polluter- and user-pays principles. Three possible causes are given for the weak relation that appears in practice between pollution and payment for services and environmental damage. The difficulties that are often encountered are the problem to designate the real originator of costs, the administrative and political motives that play a role in deciding whether or not a group or company is addressed financially, and the fact that companies have found a way to avoid high water quality charges by pre-cleaning discharges before delivering it to sewage purification plants, or use the purification facilities of public utilities (and therefore, increasing the burden of fixed operational and maintenance costs of sewage purification for other parties).

The polluter-pays principle is explicitly put forward in $\mathrm{Ar}$ ticle 9 of the WFD, which deals with the recovery of the costs of water services, including environmental and resource costs. A prerequisite for the incorporation of environmental costs into water pricing processes is the availability of an adequate framework for valuation. Although the Water Framework Directive needs to be implemented in all Member States, this does not guarantee that the same level of cost-recovery will be achieved throughout Europe. Not only can the interpretation of to concept of 'cost recovery' diverge; the nature of ecosystem functions that are considered, and the extent to which they are considered can vary. There is also a wide array of methodologies that can be used to value environmental and resource costs. Even if the views on which valuation methods to use were to converge across different Member States, the assumptions that are made when using the valuation techniques can still be different across countries and regions. The choice of valuation techniques will impact the assessment of the costs and this in turn will be reflected in the price consumers (households, industry, and agriculture) have to pay for their water use.

European Directives need to be transposed into national legislation, and within this process the possibilities to take into account local conditions or appeal to exemptions are often manifold. With respect to the WFD, for example, much will depend on whether water bodies are being classified as "heavily modified". Another example concerns the economic analysis of water use which has to be carried out according to 
Article 5 of the WFD, which needs to contain enough information in sufficient detail in order to make the relevant calculations necessary for taking into account the recovery of the costs of water services. However, as stated in Annex III of the Directive, the costs associated with collection of the relevant data can be taken into account in drawing up such economic analysis. These costs for data collection will be dependent on the management systems that are currently in place in the Member States. More generally, developing regulations, monitoring compliance and, where necessary, sanctioning infringements imply transaction costs that could outweigh potential benefits. These transaction costs could therefore necessitate a trade-off between a strict or weaker interpretation of environmental policy principles. Opting for a stringent approach might, providing that social objectives are not compromised on the other hand induce a mentality change on the longer term, and this institutional change might in turn provide an answer to the pollution problems at stake.

There are however, several caveats. Valuation processes are only one example of the numerous important issues that need to be considered with respect to the polluter-pays principle, as well as other environmental principles of policy. The way in which property rights are defined may delimit the number of choices governments face when applying the principles. Making polluters pay requires adequate metering systems for the various sectors. Their current use also depends on the local circumstances. Current prices, income levels and price elasticities are all elements to be taken into consideration as well. Efforts that have been made in the past to protect the environment should be acknowledged. The stringency of existing environmental standards, the efficiency of current monitoring and administrative structures and the level of past investments will determine what efforts remain to be made to e.g. reach "good surface and groundwater status". Much depends on the way in which the water supply and sanitation sector are organized: countries such as France where the market is open to private parties will face different challenges than countries such as The Netherlands which favour public initiative. The number and type of operators influences the costs associated with data collection and the difficulties that are encountered in negotiation processes. Conversely, the costs entailed by the WFD can in turn necessitate reforms within the sector.

\section{Conclusion}

Environmental policy principles, such as the polluter-pays principle and the precautionary approach have gained increasing importance in the management of water resources. The same is true for the concepts of integrated water management and water management based on river basins. A river basin approach implies the integration of policy-making and management throughout a set of different functional uses and spatial scales. The way in which water services are regarded and which principles are applied may vary radically between Member States. This can be illustrated with respect to the recovery of costs of water services, while taking into account the polluter-pays principle, which is put forward in Article 9 of the
European Water Framework Directive. Even if the "cost of water services" were to be defined in exactly the same way, estimations of the costs can diverge, not only because of local conditions but also depending on the valuation methods that are used or the assumptions that have been made. Water management, based on the notion of river basins necessitates a coordinated action. In order to mitigate the conflicts of interest that might emerge, the importance of the institutional context should be given careful consideration. Functional and spatial integration in the context of river basins will require a consistent application and prioritization of environmental principles of policy, which can be facilitated by an adequate regulatory framework and the presence of strong river basin authorities.

\section{Acknowledgements}

Part of this research has been carried out in the framework of the EU-project EUROMARKET ("Water liberalisation scenarios: An empirical analysis of the evolution of the European water supply and sanitation sectors", January 2003 to December 2005, EVK1-CT-2002-001113). The financial support of the European Commission is very much acknowledged. Views expressed in this paper represent solely the positions of the authors and do not necessarily correspond to those of the European Commission. A.C. gratefully acknowledges the support of the Next Generation Infrastructures Public Values project.

\section{References}

[1] European Environment Agency. $<$ http://glossary.eea.eu.int/EEAGlossary $>$; 2005.

[2] UNCED. Rio Declaration on Environment and Development, Report of the United Nations Conference on Environment and Development, Rio de Janeiro, 3-14 June; 1992.

[3] OECD. Recommendation on guiding principles concerning international economic aspects of environmental policies, C(72)128; 1972.

[4] Tobey JA, Smets H. The polluter-pays principle in the context of agriculture and the environment. World Economy 1996;19(1):63-88.

[5] OECD. The polluter-pays principle, OECD Analyses and Recommendations, Environment Directorate, OCDE/GD (92) 81; 1992.

[6] Osmanczyk EJ. The encyclopedia of the United Nations and International Agreements. London: Taylor and Francis; 1985.

[7] EU. Declaration of the Council of the European Communities and the representatives of the Governments of the Member States meeting in the Council on 22 November 1973 on the programme of action of the European Communities on the Environment, OJ C 112, 20/12/1973; 1973.

[8] EU. Resolution of the Council of the European Communities and the representatives of the Governments of the Member States meeting within the Council of 17 May 1977 on the continuation and implementation of a European Community policy and action programme on the environment, OJ C 139, 13/06/1977; 1977.

[9] EU. Resolution of the Council of the European Communities and the representatives of the Governments of the Member States, meeting within the Council, of 7 February 1983 on the continuation and implementation of a European Community policy and action programme on the environment (1982 to 1986), OJ C 46, 17/02/1983; 1983.

[10] EU. Resolution of the Council of the European Communities and the representatives of the Governments of the Member States, meeting within the Council of 18 October 1987 on the continuation and implementation of a European Community policy and action programme on the environment (1987-1992), OJ C 328, 7/12/1987; 1987. 
[11] Bruntland G, editor. Our common future: the World Commission on Environment and Development. Oxford: Oxford University Press; 1987.

[12] Heldeweg MA. Towards good environmental governance in Europe. European Environmental Law Review 2005;14(1):2-25.

[13] EU. Council Directive 98/83/EC of 3 November 1998 on the quality of water intended for human consumption; 1998.

[14] EU. Directive 2000/60/EC of the European Parliament and of the Council of 23 October 2000 establishing a framework for Community action in the field of water policy; 2000.

[15] UNECE. Convention on the protection and use of transboundary watercourses and international lakes, Helsinki, 17 March; 1992.
[16] UNECE. The 1992 UNECE Convention on the protection and use of transboundary watercourses and international lakes; 2004.

[17] UNCED. Agenda 21, Report of the United Nations Conference on Environment and Development, Rio de Janeiro, 3-14 June; 1992.

[18] van Hijum YJ. Financing public water management: dealing with economic costs of water use. Water Science and Technology 1998;38(11): $7-14$.

[19] EUROMARKET. Water liberalisation scenarios: An empirical analysis of the evolution of the European water supply and sanitation sectors, Deliverable 1: Analysis of the European Unions explicit and implicit policies and approaches in the larger water sector; 2003. $171 \mathrm{pp.}$ 